\title{
IGF-I, IGF-II, 'free' IGF-I and IGF-binding proteins-2 to -6 during high-dose oestrogen treatment in constitutionally tall girls
}

\author{
Raoul P A Rooman, Lieve Op De Beeck, Manou Martin ${ }^{1}$, Jaap Van Doorn ${ }^{2}$, Subburaman Mohan ${ }^{3}$ and \\ Marc V L Du Caju \\ Department of Pediatrics and ${ }^{1}$ Department of Biological Chemistry, Antwerp University Hospital, Edegem, Belgium, ${ }^{2}$ Wilhelmina Children's Hospital, \\ University Medical Center, Utrecht, The Netherlands and ${ }^{3}$ Musculoskeletal Disease Center, Jerry L Pettis Veterans Affairs Medical Center, Loma Linda, \\ California 92357, USA
}

(Correspondence should be addressed to R P A Rooman, Department of Pediatrics, Universitair Ziekenhuis Antwerpen, Wilrijkstraat 10, B-2650 Edegem, Belgium; Email: raoul.rooman@uza.be)

\begin{abstract}
Objective: To investigate the effect of high-dose oestrogen treatment on IGF-I, IGF-II, free-dissociable IGF-I and the IGF-binding proteins (IGFBP)-2 to -6 in girls with constitutional tall stature.

Methods: In patient cohort 1, blood samples were drawn before and after 3 months of daily oral treatment with $0.1 \mathrm{mg}$ ethinyloestradiol. In cohort 2, samples were collected at the end of the treatment period and 3 to 6 months afterwards. IGFs and IGFBPs were analysed by specific immunoassays and by Western ligand blot.

Results: Total IGF-I decreased significantly on oestrogen treatment and increased again after oestrogen withdrawal. Ligand blot analysis showed a clear reduction in a $34 \mathrm{kDa}$ band, corresponding to IGFBP-2, and a strong induction of a $24 \mathrm{kDa}$ band, corresponding to the non-glycosylated form of IGFBP-4. These changes were confirmed by specific immunological methods. The serum levels of IGFBP-3, IGFBP-5 and IGFBP- 6 remained unchanged during the first 3 months of treatment. In cohort 2, IGFBP-3 and IGFBP-6 increased after oestrogen withdrawal. Free-dissociable IGF-I fell to $35 \pm 4 \%$ during oestrogen therapy and rose again when the treatment was stopped.

Conclusions: Oestrogens modulate the serum concentrations of several components of the IGF system. The fall in total IGF-I is not explained by a decrease in IGFBPs but probably results from a decreased synthesis.
\end{abstract}

European Journal of Endocrinology 146 823-829

\section{Introduction}

The effect of oestrogens on the serum concentration of insulin-like growth factor-I (IGF-I) depends on the dose of oestrogen and the age of the individual. In children and adolescents, ethinyloestradiol given to induce puberty up to a dose of $0.030 \mathrm{mg}$ increases serum IGF-I (1) but doses higher than $0.100 \mathrm{mg}$, used to limit growth in constitutionally tall girls, decrease it $(2-4)$. In adults, oestrogens invariably decrease IGF-I whether given in low doses as an oral contraceptive in young adult women $(5,6)$, as hormone replacement therapy in postmenopausal women (7-15), in high doses to human volunteers (16), in acromegalics (17) or in male to female trans-sexuals (18). A similar age-dependent effect of oestrogens on IGF-I was also reported in primates (19).

This decrease in IGF-I is not the consequence of a decrease in growth hormone $(\mathrm{GH})$ secretion as shown during oestrogen treatment of acromegalics (17) and postmenopausal women $(7,11)$. Moreover, oestrogens also reduce the growth response to exogenously administered GH in hypophysectomized rats (20) or Snell dwarf mice (21).

In the circulation, IGF-I is bound to at least six different high-affinity IGF-binding proteins (IGFBPs) $(22-24)$. Since there is a $50 \%$ molar excess of binding proteins over IGF-I in serum, only a minute fraction is in the free, unbound form. Approximately 75\% of IGF-I is bound to IGFBP-3. This IGFBP-3-IGF-I complex is, by itself, bound to an acid-labile subunit (ALS) to form a ternary complex that determines the pharmacokinetics and tissue distribution of IGF-I and therefore its biological activity (23). A decrease in serum total IGF-I caused by exogenous oestrogens may therefore be the consequence of a change in IGFBP levels.

The effect of oral oestrogens on IGFBPs has only been studied in women who take oral contraceptives (6) and during hormone replacement therapy in postmenopausal women $(8,13,15,25)$. Since the effect of oestrogens on IGFBPs may also be age- and dose-dependent we measured serum total IGF-I, IGF-II, IGFBP-2, 
IGFBP-3, IGFBP-4, IGFBP-5, IGFBP-6 and free-dissociable IGF-I in tall girls who received a high dose $(0.1 \mathrm{mg} /$ day $)$ of ethinyloestradiol to limit their final height.

\section{Subjects and methods}

Twenty-four constitutionally tall girls were included in this longitudinal study, approved by the ethics committee of the Antwerp University Hospital. Informed consent was obtained from patients and parents.

The diagnosis of constitutional tall stature was based on (a) familial occurrence of tall stature (height of one or both parents $>2$ s.D. above the mean), (b) height $>2$ S.D. above the mean for age, according to the standards of Freeman et al. (26), (c) predicted height of more than $180 \mathrm{~cm}$ and (d) exclusion of endocrine and other disorders that may explain their tall stature. Skeletal age was evaluated by X-ray of the left hand according to the method of Greulich \& Pyle (27). Final height was predicted by the method of Bayley \& Pinneau (28). The standard deviation score of the body mass index for age (BMI-SDS) was calculated using the reference data of Cole et al. (29).

Ethinyloestradiol $(0.1 \mathrm{mg})$ was given every day at bedtime. This treatment was supplemented with $10 \mathrm{mg}$ medroxyprogesterone acetate (Farlutal, Pharmacia) for the first 12 days of each month.

In 16 patients, blood samples were collected between 0900 and $1200 \mathrm{~h}$ at the start of therapy and after 2 to 4 months of treatment (cohort 1). In eight other patients, samples were collected at the end of 2 to 3 years of therapy and 3 to 6 months afterwards (cohort 2).

Total IGF-I was measured by radioimmunoassay (Biosource Europe, Nivelles, Belgium) after acid-ethanol extraction (30). Interassay variability was less than $10 \%$. The concentration of IGF-II was determined after Sep-Pak C18 column extraction by a specific radioimmunoassay (31). IGFBP-2 was analysed by a radioimmunoassay developed by Diagnostic Systems Laboratories (DSL 7100; Webster, TX, USA) using a rabbit polyclonal IGFBP-2 antiserum. IGFBP-3 was measured in a solid phase immunoradiometric assay (BC 1040; Biocode, Liege, Belgium) using a mouse anti-IGFBP-3 monoclonal antibody. Serum IGFBP-4 levels were determined by a radioimmunoassay using recombinant human IGFBP-4 as tracer and standard, and antibodies against recombinant human IGFBP-4 raised in guinea pigs (32). Serum IGFBP-5 levels were determined by a radioimmunoassay using recombinant human IGFBP-5 as tracer and standard, and antibodies against recombinant human IGFBP-5 raised in guinea pigs (33). IGFBP-6 was measured by radioimmunoassay using a rabbit polyclonal antiserum raised against a synthetic fragment containing residues 90-118 that was also used as a tracer. Technical details and data on reproducibility and stability after storage have been described elsewhere (34).

Easy dissociable or 'free' IGF-I was measured by a two-site immunoradiometric assay (DSL 9400; Diagnostic Systems Laboratories). The paired blood samples were always measured in the same assay and expressed as a fraction of their control. For cohort 1, the sample before treatment was set at $100 \%$; in cohort 2, the sample at the end of treatment was designated as the control.

Ligand blot analysis was performed as described previously (35). Briefly, serum $(1-3 \mu \mathrm{l})$ was diluted in Laemmli sample buffer and separated by electrophoresis on a $12 \%$ SDS polyacrylamide gel in non-reducing conditions. The size-separated proteins were semi-dry blotted on nitrocellulose and incubated with biotinylated IGF-I for $1 \mathrm{~h}$ at room temperature. After washing, the membrane was incubated with streptavidin-horseradish peroxidase and the bound IGF-I was visualized by enhanced chemiluminescence on ECL Hyperfilm (Amersham International plc, Amersham, Bucks, UK).

The results were analysed by Student's t-test for paired data.

\section{Results}

Table 1 summarizes the characteristics of the two patient cohorts. In cohort 1 , treatment was started at a median calendar age of 13.7 years and a bone age of 13.25 years. Treatment was stopped in cohort 2 at a median bone age of 16.0 years when the median height was $178.5 \mathrm{~cm}$.

The changes in total IGF-I, IGF-II and free-dissociable IGF-I are shown in Fig. 1. Total IGF-I decreased from $528 \pm 31 \mathrm{ng} / \mathrm{ml}$ (mean \pm S.E.M.) to $376 \pm 27 \mathrm{ng} / \mathrm{ml}(n=$ 16 paired values, $P=0.0001$ ) after 2 to 4 months of treatment. The total IGF-I value in eight other girls at the end of treatment was $243 \pm 29 \mathrm{ng} / \mathrm{ml}$ and increased to $354 \pm 27 \mathrm{ng} / \mathrm{ml} 3$ to 6 months after ending treatment ( $n=8$ paired values, $P=0.013)$. Free-dissociable IGF-I was measured in thirteen out of sixteen patients in cohort 1 and in five out of eight in cohort 2. Freedissociable IGF-I fell to $37 \pm 4 \%$ after 2 to 4 months of oestrogen therapy $(n=13$ pairs, $P=0.002)$ and rose again when the treatment was stopped $(n=5$

Table 1 Characteristics of the patients who started (cohort 1) or stopped (cohort 2) oestrogen therapy.

\begin{tabular}{lcccrc}
\hline & $\begin{array}{c}\text { Cohort 1 at the start } \\
\text { of treatment }\end{array}$ & & \multicolumn{2}{c}{$\begin{array}{c}\text { Cohort } 2 \text { at the end } \\
\text { of the treatment }\end{array}$} \\
\cline { 2 - 3 } \cline { 5 - 6 } & Median & Range & & Median & Range \\
\hline Age (years) & 13.7 & $11.8-15.6$ & & 16.7 & $13.1-17.8$ \\
Height (cm) & 176.9 & $172-184.7$ & 178.5 & $175.3-185.3$ \\
Bone age (years) & 13.25 & $12.0-15.0$ & & 16.0 & $15.0-16.25$ \\
BMI-SDS & -0.2 & $-2.6-2.7$ & & -0.4 & $-1.4-2.04$ \\
\hline
\end{tabular}



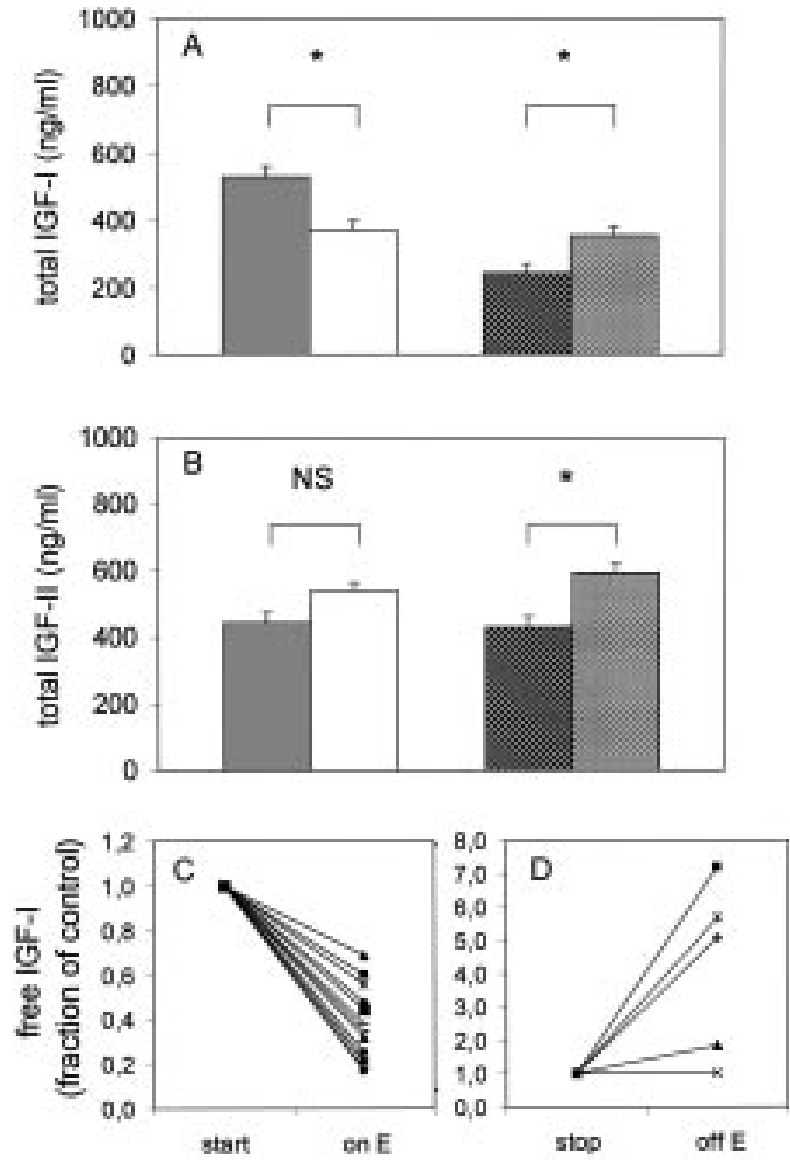

Figure 1 (A) Total IGF-I and (B) total IGF-II (mean and S.E.M.) in cohort 1 before treatment (grey bars) and after 2 to 4 months of oestrogen treatment (open bars) and in cohort 2 at the end of treatment (hatched bars) and 3 to 6 months after therapy (brick bars). NS, not significant; ${ }^{*} P \leq 0.05$ (Student's paired $t$-test). Change in free-dissociable IGF-I in (C) cohort 1 and (D) cohort 2 The paired samples were assayed simultaneously and the results are expressed as a fraction of the first measurement. E, oestrogen treatment.

pairs). IGF-II did not significantly change during oestrogen treatment (from $444 \pm 32$ to $541 \pm 32 \mathrm{ng} / \mathrm{ml}, n=10$ pairs, $P=0.12$ ) but increased in the second cohort from $430 \pm 32$ to $595 \pm 32 \mathrm{ng} / \mathrm{ml}(n=6$ pairs, $P=0.0004)$.

The changes in IGFBPs during treatment were visualized by ligand blot analysis (Fig. 2). There were no significant changes in the IGFBP-3 doublet. Oestrogen reduced a $34 \mathrm{kDa}$ band, corresponding to IGFBP-2 and strongly induced a $24 \mathrm{kDa}$ band corresponding to IGFBP-4. In the 28-32 kDa area, four other binding species were detected and the two bands with the lowest molecular weight were increased by oestrogen therapy (Fig. 2B). One of these bands was probably an IGFBP-3 fragment that was identified by Western immunoblot (Fig. 2B, lane c).

Some of the changes found by ligand blot analysis were confirmed by specific immunological methods (Fig. 3). IGFBP-2 decreased at the start of treatment

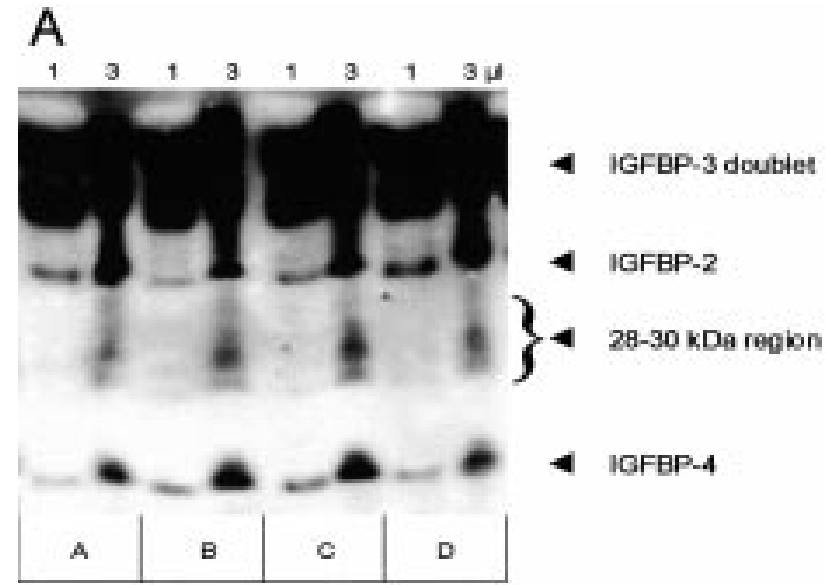

B

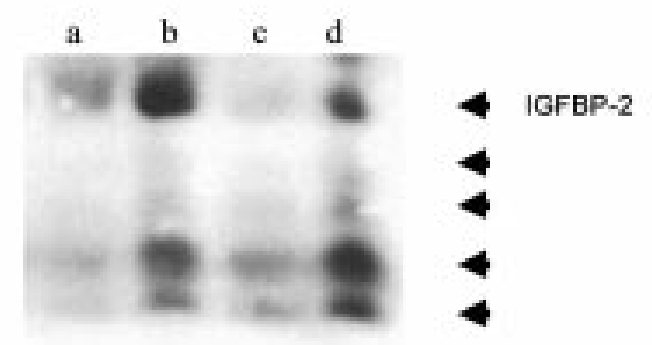

Figure 2 (A) Ligand blot of 1 and $3 \mu$ s serum from a representative patient of cohort 1 at the start (lane $A$ ) and after 3 months of therapy (lane B) and from a patient of cohort 2 at the end (lane $C$ ) and 3 months after treatment (lane D). (B) Detailed view of the region between IGFBP-2 and IGFBP-4 of the ligand blot. Note the induction of IGFBP-2, IGFBP-4 and several bands in the 28$30 \mathrm{kDa}$ region by oestrogens. Lane $\mathrm{a}$ and lane $\mathrm{b}$ are 1 and $3 \mu \mathrm{l}$ serum at the start of treatment; lane $c$ and lane $d$ represent 1 and $3 \mu \mathrm{l}$ serum after 3 months of oestrogen exposure.

from $556 \pm 48$ to $305 \pm 22 \mathrm{ng} / \mathrm{ml} \quad(n=16, \quad P=$ $0.00002)$ and increased again when the oestrogens were withdrawn $(349 \pm 47$ versus $504 \pm 52 \mathrm{ng} / \mathrm{ml}, n=$ $8, P=0.008)$. The change in IGFBP-2 correlated with the change in body weight $\left(\mathrm{R}^{2}=0.52\right)$.

IGFBP-3 levels remained unchanged during the first 3 months of treatment: from $3919 \pm 106$ to $3963 \pm$ $112 \mathrm{ng} / \mathrm{ml}(n=16, P=0.68)$. The mean IGFBP-3 of eight girls at the end of therapy was 3140土 $207 \mathrm{ng} / \mathrm{ml}$ and increased to $3664 \pm 139 \mathrm{ng} / \mathrm{ml}(P=$ $0.011) 3$ months after the end of treatment.The ratio of IGFBP-3 over total IGF-I rose at the start of treatment from $7.8 \pm 0.5$ to $11.0 \pm 0.5$ ( $P=0.00015)$.

Oestrogen treatment increased IGFBP-4 from $345 \pm 9$ to $544 \pm 22 \mathrm{ng} / \mathrm{ml} \quad(n=9, \quad P=0.0003) . \quad$ IGFBP- 4 decreased again after oestrogen withdrawal from $504 \pm 70 \quad$ to $339 \pm 17 \mathrm{ng} / \mathrm{ml} \quad(n=6, \quad P=0.11)$. 

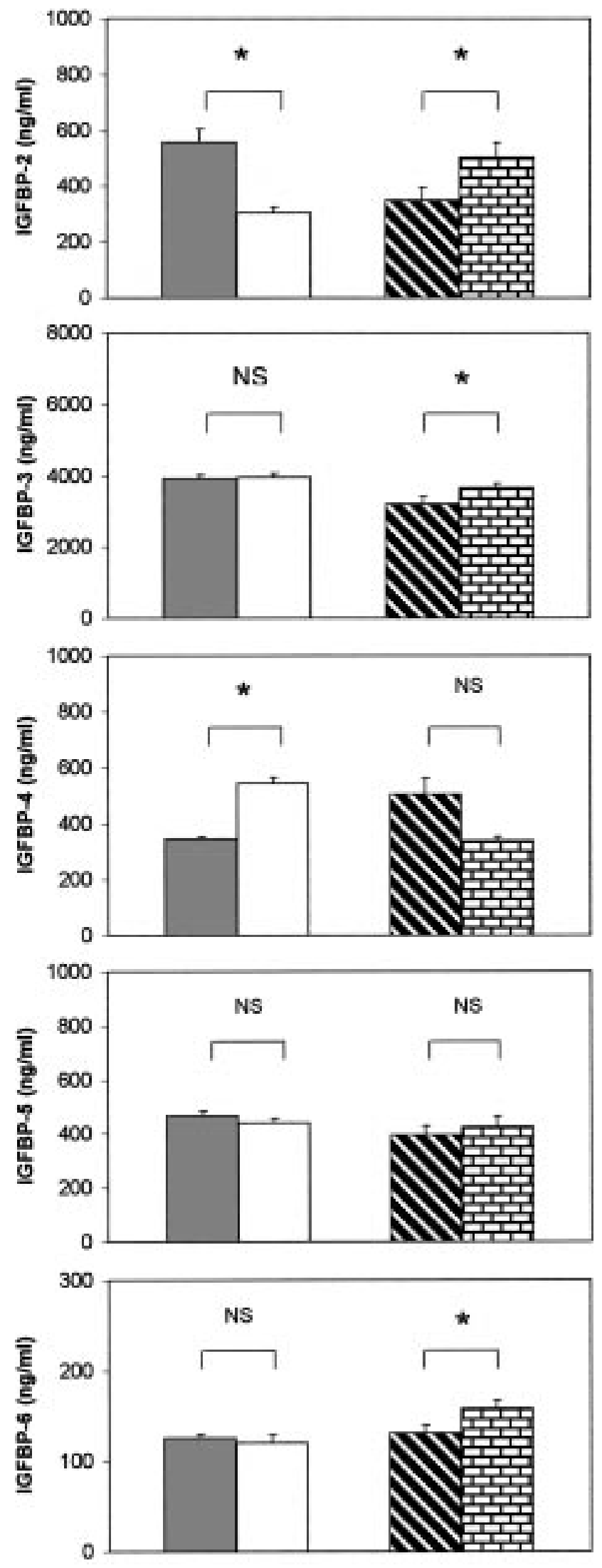

IGFBP-5 remained unaffected in cohort 1 (from $466 \pm 25$ to $441 \pm 22 \mathrm{ng} / \mathrm{ml}, n=9, P=0.32$ ) and in cohort 2 (from $370 \pm 27$ to $450 \pm 39 \mathrm{ng} / \mathrm{ml}, n=$ $6, P=0.18$ ). IGFBP-6 did not change during treatment but increased from $131 \pm 9$ to $158 \pm 9 \mathrm{ng} / \mathrm{ml}$ $(n=6, P=0.044)$ when oestrogens were stopped.

\section{Discussion}

High-dose oestrogen treatment for the reduction of final height in constitutionally tall girls reduced the levels of total IGF-I significantly as reported previously $(3,4)$. Several hypotheses have been proposed to explain this effect, such as (a) inhibition of GH secretion, (b) reduction in IGF-I synthesis or (c) a reduction in IGF serum carriers.

In a pilot experiment, we compared the blood samples from the same patient taken during the oestrogen-only period or during the oestrogen plus medroxyprogesterone period. We found no difference on the ligand blots, or for total IGF-I or IGFBP-3. Heald et al. (8) found a small antagonistic effect of medroxyprogesterone acetate on the changes induced by conjugated oestrogens in postmenopausal women. The higher dose of oestrogens in our study $(0.100 \mathrm{mg}$ ethinyloestradiol versus $0.625 \mathrm{mg}$ conjugated oestrogens) may have overriden the effect of medroxyprogesterone. We therefore pooled the data for further analysis.

We visualized the serum IGF-binding species by ligand blot before and after 2 to 4 months of oestrogen treatment. No clear changes were seen in IGFBP-3, which binds $75 \%$ of IGF-I in serum (23). This was confirmed by a radioimmunometric assay for IGFBP-3. The sharp decrease in IGF-I during oestrogen treatment can therefore not be explained by changes in IGFBP-3 levels. Since IGFBP-3 is also strongly GH-dependent, this result also rules out an acute effect of oestrogens on $\mathrm{GH}$ secretion or GH receptor expression (36). The lack of an important oestrogen effect on IGFBP-3 was also reported in postmenopausal women receiving oestrogen replacement therapy $(8,13,15,25)$. The IGFBP-3 levels in cohort 2 after 2 to 3 years of oestrogen exposure were somewhat lower than the IGFBP-3 concentrations after 2 to 4 months of oestrogen treatment in cohort 1 and rose again 3 to 6 months after treatment. Several explanations can be offered. First, it has been shown that oestrogens decrease the acidlabile subunit of the large ternary complex at least in postmenopausal women (15). The decrease in IGFBP-3 may therefore be the consequence of more rapid

Figure 3 Serum levels (means and S.E.M.) of IGFBP-2 to IGFBP-6 in cohort 1 at the start of treatment (grey bars) and after 2 to 4 months of oestrogen treatment (open bars) and in cohort 2 at the end of treatment (hatched bars) and 3 to 6 months after therapy (brick bars). NS, not significant; ${ }^{*} P \leq 0.05$ (Student's paired $t$-test). 
clearance from the circulation due to prolonged lower ALS and IGF-I levels. Alternatively, it cannot be excluded that oestrogens have a slight effect on $\mathrm{GH}$ secretion, GH receptor expression (36) or IGFBP-3 synthesis after a more chronic use. A decreased GH activity may also explain our previously reported (4) and current observation that the total IGF-I concentration further decreases during oestrogen therapy.

IGF-I levels increased again after stopping therapy but not to pretreatment values. This may be due to the age-dependent decrease in IGF-I at the end of puberty.

The concentration of IGF-II was variable among individuals but had a tendency to increase during the first few months of therapy. The levels at the end of therapy in cohort 2 were again lower. One possible explanation is that IGF-II first rises because there are more binding sites available on IGFBP-3 due to the fall of IGF-I. As IGFBP-3 levels decrease gradually with more prolonged oestrogen exposure, IGF-II also declines. The sharp rise of IGF-II after therapy may be the consequence of a rise in IGFBP-3, IGFBP-2 and/or IGFBP-6.

Slight changes were observed in two faint bands in the $28-30 \mathrm{kDa}$ region of the ligand blot. One of these bands represents a $30 \mathrm{kDa}$ IGFBP-3 fragment that can be detected by our non-radioactive ligand approach (35). This may indicate that oestrogens stimulate the proteolysis of IGFBP-3 and the generation of a $30 \mathrm{kDa}$ fragment which was shown to be a weak inhibitor of IGF-I action (37). We were unable to identify the other bands in the $28-32 \mathrm{kDa}$ region but other investigators recently found IGFBP-1, IGFBP-6, glycosylated IGFBP-4 and IGFBP-5 in this region by two-dimensional ligand blot analysis (38). Because oestrogens were reported to dramatically increase IGFBP-1 levels in postmenopausal women $(8,13)$ and women on oral contraceptives (6) one of the bands is most likely IGFBP-1. We did not measure IGFBP-1 since it has a short serum half-life and is modulated by serum insulin levels, hence requiring fasting blood samples.

Oestrogen treatment clearly decreased a $34 \mathrm{kDa}$ band on the ligand blot identified as IGFBP-2. The band became more prominent again after the end of therapy. These changes were confirmed by a radioimmunoassay for IGFBP-2. Oestrogens caused an average weight gain of $3 \mathrm{~kg}$ during the first 3 months of therapy. We were therefore not surprised to find a correlation (Pearson correlation $=0.52, P=0.056)$ between the change in IGFBP-2 and the change in weight in cohort 1. A correlation between body weight and IGFBP-2 has been reported previously $(39,40)$. However, a direct effect of oestrogens on IGFBP-2 production is not excluded. Women have lower levels of IGFBP-2 than men between the ages of 10 and 40 years (41). On the other hand, IGFBP-2 levels remained unchanged by ligand blot analysis in postmenopausal women on oral replacement therapy (8) and in women taking oral contraceptives (6).
Oestrogen therapy induced a band at $24 \mathrm{kDa}$, most likely the non-glycosylated form of IGFBP-4. This effect was reversible as the band decreased again 3 months after the end of therapy. This finding was corroborated by the direct measurement of IGFBP-4. Oestrogens were reported to stimulate IGFBP-4 mRNA and protein in a human osteoblastic cell line (42) and in the human breast cancer cell line MCF-7 (43). Serum IGFBP-4 also increased in women who take oral contraceptives (6) and in postmenopausal women on hormone replacement therapy (8). Since IGFBP-4 is considered an inhibitor of IGF-I action $(44,45)$, it may contribute to the growth inhibition by oestrogens.

During puberty, low concentrations of oestrogen increase serum IGFBP-5 levels, probably mediated by an increase in $\mathrm{GH}$ secretion (46). In this study with supraphysiological doses of oestrogens, IGFBP-5 remained unchanged during the first months of treatment, supporting the hypothesis that $\mathrm{GH}$ secretion is not affected. Similar to IGFBP-3, the concentrations of IGFBP-5 were lower in cohort 2 than in cohort 1 , which may again indicate that $\mathrm{GH}$ secretion decreases after a more chronic exposure.

IGFBP-6 remained unchanged under oestrogen therapy but increased afterwards. Since IGFBP-6 has a high affinity for IGF-II, the rise in IGFBP-6 may partly explain the increase in IGF-II in cohort 2 after treatment $(34,47)$. Our data do not support a role for oestrogens as a cause for the lower IGFBP-6 levels in females than in males (41).

Overall, oestrogens did not substantially decrease the IGF-binding capacity of serum. It is therefore highly unlikely that the drop in total IGF-I after 3 months of therapy is the consequence of a change in binding proteins. The dramatic fall in free-dissociable IGF-I that we found is also indirect evidence that the equilibrium between free and bound IGF-I is shifted. All the data therefore suggest that oestrogens directly decrease the production of IGF-I. At least three other observations support this hypothesis. First, IGF-I levels are less suppressed by transdermal oestrogen therapy as opposed to oral treatment, suggesting the importance of the local concentration of oestrogens in the liver, the predominant source of serum IGF-I (7, 25, 48). Secondly, oestrogens have been shown to inhibit hepatic mRNA synthesis for IGF-I in rats $(49,50)$ and in cultured hepatocytes (51). Finally, the type $\alpha$-oestrogen receptor was recently shown to bind to the IGF-I gene promotor in a human liver cell line. In this model, IGF-I gene transcription was stimulated by oestrogen antagonists and inhibited by oestradiol (52).

In conclusion, this study and the data reported in the literature indicate that oestrogens modulate several components of the serum IGF system. The important decrease in total IGF-I and free-dissociable IGF-I are most likely the result of an inhibitory effect of oestrogens on IGF-I synthesis. Oestrogens decrease IGFBP-2 and increase the levels of IGFBP-1, IGFBP-4 and probably 
IGFBP-3 fragments, some of which are also growth inhibitors. The contribution of these systemic alterations in the IGF system to the growth-inhibitory effects of high-dose oestrogen therapy remains unknown. Given the recent controversy on the importance of systemic versus locally produced IGF-I for growth, the circulating levels of the IGFBPs may not be relevant at all (53). The effects of oestrogen on the synthesis of components of the IGF system in the growth plate itself or actions of oestrogen that are independent of the IGF system $(54,55)$ may also be involved.

\section{Acknowledgements}

This work was supported by a grant from the Belgian Study Group for Pediatric Endocrinology.

\section{References}

1 Cuttler L, Van Vliet G, Conte FA, Kaplan SL \& Grumbach MM. Somatomedin-C levels in children and adolescents with gonadal dysgenesis: differences from age-matched normal females and effect of chronic estrogen replacement therapy. Journal of Clinical Endocrinology and Metabolism 198560 1087-1092.

2 Gourmelen M, le Bouc Y, Girard F \& Binoux M. Serum levels of insulin-like growth factor (IGF) and IGF binding protein in constitutionally tall children and adolescents. Journal of Clinical Endocrinology and Metabolism 198459 1197-1203.

3 Svan H, Ritzen EM, Hall K \& Johansson L. Estrogen treatment of tall girls: dose dependency of effects on subsequent growth and IGF-I levels in blood. Acta Paediatrica Scandinavica 199180 $328-332$.

4 Wajs-Kuto E, Op De Beeck L, Rooman RPA \& Du Caju MVL. Hormonal changes during the first year of oestrogen treatment in constitutionally tall girls. European Journal of Endocrinology $1999141579-584$.

5 Jernstrom H \& Olsson H. Suppression of plasma insulin-like growth factor-1 levels in healthy, nulliparous, young women using low dose oral contraceptives. Gynecologic and Obstetric Investigation 199438 261-265.

6 Westwood M, Gibson JM, Pennells LA \& White A. Modification of plasma insulin-like growth factors and binding proteins during oral contraceptive use and the normal menstrual cycle. American Journal of Obstetrics and Gynecology 1999180 530-536.

7 Weissberger AJ, Ho KK \& Lazarus L. Contrasting effects of oral and transdermal routes of estrogen replacement therapy on 24-hour growth hormone $(\mathrm{GH})$ secretion, insulin-like growth factor I, and GH-binding protein in postmenopausal women. Journal of Clinical Endocrinology and Metabolism 199172 374-381.

8 Heald A, Selby PL, White A \& Gibson JM. Progestins abrogate estrogen-induced changes in the insulin-like growth factor axis. American Journal of Obstetrics and Gynecology $2000 \mathbf{1 8 3}$ 593-600.

9 Kelly JJ, Rajkovic IA, O'Sullivan AJ, Sernia C \& Ho KK. Effects of different oral oestrogen formulations on insulin-like growth factor-I, growth hormone and growth hormone binding protein in post-menopausal women. Clinical Endocrinology 199339 $561-567$.

10 O'Sullivan AJ, Crampton LJ, Freund J \& Ho KK. The route of estrogen replacement therapy confers divergent effects on substrate oxidation and body composition in postmenopausal women. Journal of Clinical Investigation 1998102 1035-1040.
11 Dawson-Hughes B, Stern D, Goldman J \& Reichlin S. Regulation of growth hormone and somatomedin-C secretion in postmenopausal women: effect of physiological estrogen replacement. Journal of Clinical Endocrinology and Metabolism 198663 424-432.

12 Duursma SA, Bijlsma JW, Van Paassen HC, Buul-Offers SC \& Skottner-Lundin A. Changes in serum somatomedin and growth hormone concentrations after 3 weeks oestrogen substitution in post-menopausal women; a pilot study. Acta Endocrinologica $1984106527-531$.

13 Helle SI, Omsjo IH, Hughes SC, Botta L, Huls G, Holly JM et al. Effects of oral and transdermal oestrogen replacement therapy on plasma levels of insulin-like growth factors and IGF binding proteins 1 and 3: a cross-over study. Clinical Endocrinology 1996 $45727-732$.

14 Frohlander N \& von Schoultz B. Growth hormone and somatomedin $\mathrm{C}$ during post-menopausal replacement therapy with oestrogen alone and in combination with an antioestrogen. Maturitas $19889297-302$.

15 Kam GY, Leung KC, Baxter RC \& Ho KK. Estrogens exert routeand dose-dependent effects on insulin-like growth factor (IGF)binding protein-3 and acid-labile subunit of the IGF ternary complex. Journal of Clinical Endocrinology and Metabolism 2000 $851918-1922$.

16 Wiedemann E, Schwartz E \& Frantz AG. Acute and chronic estrogen effects upon serum somatomedin activity, growth hormone, and prolactin in man. Journal of Clinical Endocrinology and Metabolism $1976 \mathbf{4 2} 942-952$.

17 Clemmons DR, Underwood LE, Ridgway EC, Kliman B, Kjellberg RN \& Van Wyk JJ. Estradiol treatment of acromegaly. Reduction of immunoreactive somatomedin- $\mathrm{C}$ and improvement in metabolic status. American Journal of Medicine 198069 571-575.

18 Meyer WJ 3rd, Furlanetto RW \& Walker PA. The effect of sex steroids on radioimmunoassayable plasma somatomedin C concentrations. Journal of Clinical Endocrinology and Metabolism $1982551184-1187$.

19 Wilson ME. Effects of estradiol and exogenous insulin-like growth factor I (IGF-I) on the IGF-I axis during growth hormone inhibition and antagonism. Journal of Clinical Endocrinology and Metabolism $1998 \mathbf{8 3} 4013-4021$.

20 Josimovich JB, Mintz DH \& Finster JL. Estrogenic inhibition of growth hormone-induced tibial epiphyseal growth in hypophysectomized rats. Endocrinology 196781 1428-1430.

21 Holder AT, Clark RG \& Preece MA. Prolonged oestrogen treatment inhibits growth hormone-induced growth in hypopituitary dwarf mice. Journal of Endocrinology 198396 451-456.

22 Jones JI \& Clemmons DR. Insulin-like growth factors and their binding proteins: biological actions. Endocrine Reviews 199516 $3-34$.

23 Rajaram S, Baylink DJ \& Mohan S. Insulin-like growth factorbinding proteins in serum and other biological fluids: regulation and functions. Endocrine Reviews 199718 801-831.

24 Kelley KM, Oh Y, Gargosky SE, Gucev Z, Matsumoto T, Hwa V et al. Insulin-like growth factor-binding proteins (IGFBPs) and their regulatory dynamics. International Journal of Biochemistry and Cell Biology 199628 619-637.

25 Bellantoni MF, Vittone J, Campfield AT, Bass KM, Harman SM \& Blackman MR. Effects of oral versus transdermal estrogen on the growth hormone/insulin-like growth factor I axis in younger and older postmenopausal women: a clinical research center study. Journal of Clinical Endocrinology and Metabolism $1996 \mathbf{8 1}$ $2848-2853$.

26 Freeman JV, Cole TJ, Chinn S, Jones PR, White EM \& Preece MA. Cross sectional stature and weight reference curves for the UK, 1990. Archives of Diseases in Childhood 199573 17-24.

27 Greulich WW, Pyle SI. Radiographic Atlas of Skeletal Development of the Hand and Wrist, edn 2. Stanford: Stanford University Press, 1959.

28 Bayley N \& Pinneau SR. Tables for predicting adult height from skeletal age: revised for use with the Greulich-Pyle hand standards. Journal of Pediatrics $195240423-441$. 
29 Cole TJ, Freeman JV \& Preece MA. Body mass index reference curves for the UK, 1990. Archives of Diseases in Childhood 1995 $7325-29$.

30 Daughaday WH, Mariz IK \& Blethen SL. Inhibition of access of bound somatomedin to membrane receptor and immunobinding sites: a comparison of radioreceptor and radioimmunoassay of somatomedin in native and acid-ethanol-extracted serum. Journal of Clinical Endocrinology and Metabolism $1980 \mathbf{5 1}$ $781-788$.

31 Hokken-Koelega AC, Hackeng WH, Stijnen T, Wit JM, de Muinck Keizer-Schrama SM \& Drop SL. Twenty-four-hour plasma growth hormone $(\mathrm{GH})$ profiles, urinary GH excretion, and plasma insulinlike growth factor-I and -II levels in prepubertal children with chronic renal insufficiency and severe growth retardation. Journal of Clinical Endocrinology and Metabolism 199071 688-695.

32 Honda Y, Landale EC, Strong DD, Baylink DJ \& Mohan S. Recombinant synthesis of insulin-like growth factor-binding protein-4 (IGFBP-4): development, validation, and application of a radioimmunoassay for IGFBP-4 in human serum and other biological fluids. Journal of Clinical Endocrinology and Metabolism $1996 \mathbf{8 1}$ 1389-1396.

33 Mohan S, Libanati C, Dony C, Lang K, Srinivasan N \& Baylink DJ. Development, validation, and application of a radioimmunoassay for insulin-like growth factor binding protein-5 in human serum and other biological fluids. Journal of Clinical Endocrinology and Metabolism $1995 \mathbf{8 0} 2638-2645$.

34 Van Doorn J, Ringeling AM, Shmueli SS, Kuijpers MC, HokkenKoelega AC, Buul-Offers SC et al. Circulating levels of human insulin-like growth factor binding protein-6 (IGFBP-6) in health and disease as determined by radioimmunoassay. Clinical Endocrinology $199950601-609$.

35 Op De Beeck L, Verlooy JE, Buul-Offers SC \& Du Caju MV. Detection of serum insulin-like growth factor binding proteins on Western ligand blots by biotinylated IGF and enhanced chemiluminescence. Journal of Endocrinology 1997154 R1-R5.

36 Bennett PA, Levy A, Carmignac DF, Robinson IC \& Lightman SL. Differential regulation of the growth hormone receptor gene: effects of dexamethasone and estradiol. Endocrinology 1996137 3891-3896.

37 Durham SK, Mohan S, Liu F, Baker BK, Lee PD, Hintz RL et al. Bioactivity of a 29-kilodalton insulin-like growth factor binding protein-3 fragment present in excess in chronic renal failure serum. Pediatric Research 199742 335-341.

38 Weber MM, Spottl G, Gossl C \& Engelhardt D. Characterization of human insulin-like growth factor-binding proteins by two-dimensional polyacrylamide gel electrophoresis and Western ligand blot analysis. Journal of Clinical Endocrinology and Metabolism 199984 1679-1684.

39 Nam SY, Lee EJ, Kim KR, Cha BS, Song YD, Lim SK et al. Effect of obesity on total and free insulin-like growth factor (IGF)-1, and their relationship to IGF-binding protein (BP)-1, IGFBP-2, IGFBP-3, insulin, and growth hormone. International Journal of Obesity and Related Metabolic Disorders 199721 355-359.

40 Argente J, Caballo N, Barrios V, Pozo J, Munoz MT, Chowen JA et al. Multiple endocrine abnormalities of the growth hormone and insulin-like growth factor axis in prepubertal children with exogenous obesity: effect of short- and long-term weight reduction. Journal of Clinical Endocrinology and Metabolism 1997 82 2076-2083.

41 Yu H, Mistry J, Nicar MJ, Khosravi MJ, Diamandis A, Van Doorn J et al. Insulin-like growth factors (IGF-I, free IGF-I and IGF-II) and insulin-like growth factor binding proteins (IGFBP-2, IGFBP-3, IGFBP-6, and ALS) in blood circulation. Journal of Clinical Laboratory Analysis 199913 166-172.
42 Kassem M, Okazaki R, De Leon D, Harris SA, Robinson JA, Spelsberg TC et al. Potential mechanism of estrogen-mediated decrease in bone formation: estrogen increases production of inhibitory insulin-like growth factor-binding protein-4. Proceedings of the Association of American Physicians $1996 \mathbf{1 0 8}$ 155-164.

43 Qin C, Singh P \& Safe S. Transcriptional activation of insulin-like growth factor-binding protein-4 by $17 \beta$-estradiol in MCF-7 cells: role of estrogen receptor-Sp1 complexes. Endocrinology 1999 $1402501-2508$.

44 Miyakoshi N, Richman C, Qin X, Baylink DJ \& Mohan S. Effects of recombinant insulin-like growth factor-binding protein- 4 on bone formation parameters in mice. Endocrinology $19991405719-$ 5728.

45 Rees C, Clemmons DR, Horvitz GD, Clarke JB \& Busby WH. A protease-resistant form of insulin-like growth factor (IGF) binding protein 4 inhibits IGF-1 actions. Endocrinology $1998 \mathbf{1 3 9}$ 4182-4188.

46 Libanati C, Baylink DJ, Lois-Wenzel E, Srinvasan N \& Mohan S. Studies on the potential mediators of skeletal changes occurring during puberty in girls. Journal of Clinical Endocrinology and Metabolism $1999842807-2814$.

47 Baxter RC \& Saunders H. Radioimmunoassay of insulin-like growth factor-binding protein-6 in human serum and other body fluids. Journal of Endocrinology 1992134 133-139.

48 Cano A, Castelo-Branco C \& Tarin JJ. Effect of menopause and different combined estradiol-progestin regimens on basal and growth hormone-releasing hormone-stimulated serum growth hormone, insulin-like growth factor-1, insulin-like growth factor binding protein (IGFBP)-1, and IGFBP-3 levels. Fertility and Sterility $199971261-267$.

49 Murphy LJ \& Friesen HG. Differential effects of estrogen and growth hormone on uterine and hepatic insulin-like growth factor I gene expression in the ovariectomized hypophysectomized rat. Endocrinology $1988 \mathbf{1 2 2} 325-332$.

50 Borski RJ, Tsai W, DeMott-Friberg R \& Barkan AL. Regulation of somatic growth and the somatotropic axis by gonadal steroids: primary effect on insulin-like growth factor I gene expression and secretion. Endocrinology 1996137 3253-3259.

51 Krattenmacher R, Knauthe R, Parczyk K, Walker A, Hilgenfeldt U \& Fritzemeier KH. Estrogen action on hepatic synthesis of angiotensinogen and IGF-I: direct and indirect estrogen effects. Journal of Steroid Biochemistry and Molecular Biology 1994 48 207-214.

52 Fournier B, Gutzwiller S, Dittmar T, Matthias G, Steenbergh P \& Matthias P. Estrogen receptor (ER)-alpha, but not ER-beta, mediates regulation of the insulin-like growth factor I gene by antiestrogens. Journal of Biological Chemistry $200127635444-35449$.

53 D'Ercole AJ \& Calikoglu AS. Editorial review: the case of local versus endocrine IGF-I actions: the jury is still out. Growth Hormone and IGF Research $200111261-265$.

54 van der Eerden BC, Karperien M \& Wit JM. The estrogen receptor in the growth plate: implications for pubertal growth. Journal of Pediatric Endocrinology and Metabolism 200114 (Suppl 6) 1527-1533.

55 Wolthers T, Hoffman DM, Nugent AG, Duncan MW, Umpleby M \& Ho KK. Oral estrogen antagonizes the metabolic actions of growth hormone in growth hormone-deficient women. American Journal of Physiology, Endocrinology and Metabolism $2001 \quad \mathbf{2 8 1}$ E1191-E1196.

Received 5 December 2001

Accepted 21 March 2002 